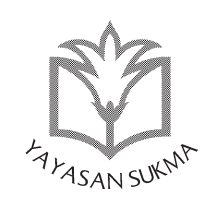

SUKMA: JURNAL PENDIDIKAN

ISSN: 2548-5105

Volume 1 Issue 1, Jan-Jun 2017, hlm. 131-175

\title{
PENGEMBANGAN DAYA KREATIF (CREATIVE POWER) MELALUI DUNIA SEKOLAH Identifikasi Isu $^{1}$
}

Fuad Fachruddin

Sekolah Sukma Bangsa Aceh, Indonesia

email: fuadfachruddin5@gmail.com

\section{Abstrak}

Setiap insan dianugrahi Yang Maha Penyayang daya kreatif (creative power), yang mengandung beberapa dimensi yaitu berfikir kreatif (creative thinking atau divergent thinking), perilaku kreatif (creative

1. Tulisan merupkan hasil edit ulang dari tulisan yang disaajikan pada "Sarasehan Nasional tentang Pendidikan Pengembangan Ekonomi Kreatif pada Satuan Pendidikan," yang diselenggarakan pada Mei 2011. Tulisan ini sebagai pendamping dari draf "Pedoman Umum Pendidikan Pengembangan Ekonomi Kreative pada Satuan Pendidikan" yang penulis sebagai penulis dan ketua tim kecil. Terimakasih untuk Sdr. Ihsam yang telah memberi masukan dan anggota lain yang maaf penulis tidak dapat menyebutkan namanya. 
behavior) atau perilaku konstruktif (constructive behavior) dan tindakan atau amaliah kreatif. Sayang tidak semua orang dapat mengembangkan daya tersebut secara optimal. Pola dan pendekatan mendidik di keluarga, sekolah dan masyarakat acap kali tidak mendukung pengembangan daya kreatif. Tulisan ini membahas beberapa hal seperti tersebut di muka dan pengembangan daya kreatif melalui dunia sekolah. Dalam mengembangkan daya kreatif peserta didik diperlukan hal atau syarat yang mendukung yaitu guru kreatif yang mencakup pembelajaran kreatif (creative teaching), kepala sekolah yang kreatif (creative leadership) dan lingkungan yang kreatif. Pengembangan daya kreatif dalam kontek bangsa untuk menyiapkan warga bangsa dalam mengadapi kehidupan yang sangat kompetitif (global). Dalam kontek dunia sekolah, pengembangan daya kreatif dimaksudkan sebagai sebagai salah satu upaya peningkatan mutu pendidikan, karena pengembangan daya akan melahirkan superior learning. Pengembangan daya kreatif peserta didik dapat dilakukan melalui pendekatan atau metoda seperti memecahkan masalah secara kreatif (creative problem solving), pembelajaran berbasis masalah, konsep dan pendekatan "limit to reach unlimited (dalam keadaan terbatas dapat melahirkan karya luar biasa).

Kata Kunci: daya kreatif; berfikir kreatif; berfikir divergen; perilaku kreatif; proses kreatif

\section{Latar Belakang}

Kreatifitas telah muncul kembali dan menjadi isu penting terutama setelah krisis ekonomi Amerika pada 2008 yang mempengaruhi ekonomi dunia. Pada 2009 Presiden RI mengeluarkan INPRES No 6 tentang "pendidikan pengembangan ekonomi 
Pengembangan Daya Kreatif (Creative Power) Melalui Dunia Sekolah

kreatif" sebagai landasan hukum untuk melakukan usaha-usaha yang diperlukan bagi pengembangan potensi atau daya kreatif (creative power) warga bangsa dalam menghadapi tantangan kehidupan yang sangat kompetitif (global). Ada beberapa hal penting yang dapat dijadikan landasan program peningkatan pengembangan daya kreatif melalui dunia sekolah (pendidikan).

Pertama, globalisasi merupakan proses integrasi penduduk dunia menjadi satu warga masyarakat dunia (world citizen). Globalisasi merupakan proses percepatan internasionalisasi dari pelbagai dimensi kehidupan, dan terhubungkan kehidupan suatu bangsa dengan bangsa lain melalui jaringan global. Globalisasi juga dicirikan dengan tingkat kompetisi yang tinggi. Dengan demikian, globalisasi memberi pengaruh terhadap tatanan kehidupan, seperti ekonomi, politik, budaya, teknologi dan pendidikan (Sholte, 2000; Cohen \& Kennedy, 2000; Steger, 2001; Fachruddin, 2008).

Dari sisi ekonomi, persaingan ketat dapat ditengarai, misalnya, dengan flow barang atau tenaga kerja dari suatu Negara ke Negara lain sebagai konsekwensi dari pasar terbuka. Dari dimensi politik, arus globalisasi memberi tantangan terhadap kedaulatan suatu Negara. Para pengambil keputusan tingkat Negara akan dihadapkan pada tekanan eksternal dari institusi transnasional ("a certain loss of nation-state and a weakening of the notion of the "citizen as a unified and verifying concept"). Pada era ini, setiap bangsa juga akan dihadapkan kepada arus budaya luar atau dunia berkat kemajuan teknologi informasi (dunia maya, misalnya), yang dapat memberi dampak yang saling tarik menarik (trade off) terhadap budaya setempat atau "identitas diri" (self identify) warga suatu bangsa.

Beberapa ahli sepakat bahwa pendidikan merupakan kunci yang sangat diharapkan dapat memainkan peran dalam merespon tuntutan global. Dunia pendidikan dihadapkan kepada tuntutan seperti fleksibilitas dan adaptif, misalnya, untuk menyahuti tuntutan dan kesempatan dunia kerja-meningkatkan kemampuan pekerja. Sekolah dan pembelajaran hendaknya 


\section{Fuad Fachruddin}

memberi bekal yang diperlukan untuk hidup berdampingan dengan mereka yang berlatarbelakang sosio-kultural, politik, idiologi dan agama yang berragam. Pembelajaran dapat membantu mengokohkan sense of identity dalam keragaman afiliasi pandangan, faham atau idiologi (Burbules \& Torres, 2000: 20-22; Cohen \& Kennedy, 2000). Dunia pendidikan dihadapkan pada dorongan global untuk membenahi konsep, sistem dan mutu pendidikan. Pada era global, mutu lembaga pendidikan suatu negara dinilai secara internasional dan disandingkannya dengan mutu lembaga pendidikan negara lainnya melalui instrumen, misalnya, TIMSS(Trends in Mathematic and Science Study) dan PISA (Programme for International Student Assessment). Lembaga pendidikan seperti sekolah, perguruan tinggi termasuk pendidik dituntut memiliki kemampuan lebih disandingkan dan ditandingkan dengan lembaga pendidikan dan pendidik negara di dunia, sehingga para lulusan sekolah dan perguruan termasuk pendidik suatu negara, seperti Indonesia, mampu berperan dalam era sejagat (Burnouf, 2004; Carnoy, 1999; Zajda, 2005; Fachruddin, 2010; Fachruddin, 2008).

Kedua, perubahan yang terjadi dalam dunia berjalan secara cepat dan menuntut setiap orang secara konstan dapat menyelesaikan tugas dan persoalan dengan cara baru. Era ini menuntut orang untuk selalu belajar (belajar seumur hidup) untuk mengupdate apa yang dimilki dan orang perlu memikirkan cara-cara baru dalam menghadapi persoalan kehidupan. Persoalan hidup yang ditemukan di lingkungan keluarga, masyarakat atau bangsa lebih komplek [termasuk konflik] yang menuntut kita untuk berfikir kreatif dan divergent dalam menyelesaikannya (Robert Sternberg, 2007; Caudeli, 2003; Hick, 2003; Cropley, 1997). Dalam merespon perkembangan kehidupan yang cepat (ilmu dan teknologi), suatu bangsa seperti Indonesia memerlukan pemikir-pemikir kreatif dan teknokrat kreatif. Pada sisi lain kreatif atau kreatifitas merupakan satu representasi karakter dan penumbuhannya kepada warga bangsa akan memberikan makna terhadap peningkatan harkat dan martabat bangsa (manusia).

Ketiga, lapangan kerja yang akan diisi oleh anak-anak kita 
yang masih menempuh pendidikan belum juga nampak jelas. Sementara itu apa yang diberikan sekolah, yaitu pengetahuan dan keterampilan, tidak dapat secara langsung diterapkan dalam sebagian kehidupan mereka. Keterampilan dan pengetahuan yang diperlukan untuk kehidupan (dunia kerja) mendatang tidak diketahui secara pasti seperti apa pada saat ini (sekarang). Oleh sebab itu, pengetahuan yang diwariskan kepada anak bangsa perlu inovatif dan adaptif terhadap perubahan yang terjadi. Para peserta didik perlu dibekali dengan pengetahuan dan keterampilan yang adaptif terhadap perubahan (kemajuan). Sementara itu, masyarakat sangat membutuhkan warganya yang memiliki karakter inventif, bermanfaat, cekatan (fleksibel) dan adaptif dalam menghadapi perubahan-perubahan yang cepat. Kemampuan sekolah mengembangkan kemampuan berfikir kreatif di kalangan peserta didik mempunyai peran sangat penting (Cropley, 1997), karena pendidik merupakan determinan dalam pelaksanannya. Untuk itu, kemampuan professional para pendidik yang meliputi content, pedagogical skill dan soft skills (yang termasuk kreatif, menghargai identitas diri sendiri berbarengan dengan menghargai identitas orang, terbuka) perlu terus ditingkatkan melalui berbagai skema progam agar para pendidik kita memiliki kemampuan tingkat dunia (globally competent teachers).

Keempat, kreatifitas merupakan "kekayaan pribadi" (personal properties) yang diwujudkan dalam sikap atau karakter seperti fleksibel, terbuka, otonom, lapang dada, keinginan mencoba sesuatu (penasaran), firm (strong minded), kemampuan menjabarkan gagasan, kemampuan menilai diri sendiri secara realistis (mengenal dirinya = 'arafa nafsahu) yang kesemuanya diperlukan (prasyarat) untuk memunculkan kreaifitas. Pengembangan kreatifitas dalam kelas (pembelajaran) akan menghasilkan peserta didik kreatif dan peserta didik yang kreatif pada umumnya memiliki kemampuan lebih tinggi dan tangguh dibanding peserta didik biasa [tidak kreatif]. Kemampuan berfikir kreatif sebagai komponen kreatif akan menghasilkan pembelajaran efektif atau lebih jauh mengembangkan daya nalar 
tinggi yang dapat digunakan untuk mengatasi persoalan pembelajaran. Pengembangan potensi kreatif peserta didik akan menghasilkan superior learning. Peserta didik yang memiliki kemampuan berfikir kreatif akan memiliki motivasi intrinsik yang tinggi dalam belajar dan memiliki daya dorong kuat, percaya diri dan kemampuan berfikir yang tinggi. Juga pengembangan kemampuan berfikir divergent sebagai elemen kreatif akan memperbaiki sikap seseorang dalam belajar dan meningkatkan motivasi belajar atau cara yang ampuh mendorong seseorang belajar (Cropley, 1997; Fisher \& Williams, 2004). Dengan kata lain, kreatifitas memberikan kemampuan yang diperlukan untuk menghadapi kehidupan mendatang yang tidak menentu (uncertainty). Berfikir kreatif merupakan unsur penting untuk mewujudkan pembelajaran berhasil (successful learning) atau pendidikan bermutu dan keberhasilan dalam kehidupan (Fisher \& Williams, 2004).

Kelima, kesehatan mental dan kreatifitas mempunyai hubungan dengan kreatif. Ide tentang relasi antara kreatifitas dan kesehatan mental merupakan isu lama dalam psikologi. Konsep diri (self) dan aktualiasi diri (self actualization) merupakan kunci atau jantung dari pengembangan kepribadian yang sehat. Maslow $(1954,1971)$ dan Rogers (1961), dalam studi klasiknya, menekankan pentingnya sikap atau karakter "terbuka, fleksibel dan toleran" bagi kesehatan mental. Dengan kata lain, menumbuhkan atau mengembangkan potensi kreatif individu warga masyarakat akan meningkatkan kesehatan mental khususnya dalam pengertian "aktualisasi diri" (Cropley, 1997; Fisher \& Williams, 2004).

Berdasarkan pertimbangan tersebut di atas, pengembangan kreatifitas dalam dunia pendidikan atau sekolah (yang meliputi isu=isu pembelajaran kreatif, sekolah kreatif, guru kreatif, pimpinan sekolah kreatif, dan murid kreatif serta lingkungan yang kondusif terhadap penumbuhan kreatifitas) penting mengingat dunia pendidikan kita masih dihadapkan kepada persoalan mendasar, misalnya pemerataan mutu hasil pembelajaran, mutu pembelajaran, akses pendidikan bermutu 
bagi seluruh warga bangsa, kompetensi guru, dan sumber pendidikan serta keadaan geografis. Kemampuan mengubah persoalan atau keterbatasan yang ditemukan dalam penyelenggaraan pendidikan di tingkat kelas (pembelajaran) pada satuan pendidikan akan menjadi energi dan pendorong bagi pengembangan potensi kreatif (actual) di kalangan masyarakat sekolah merupakan bagian penting dalam menyiapkan warga bangsa menghadapi tantangan global. Oleh sebab itu, pembelajaran yang mendorong tumbuhnya kreatifitas, berfikir kreatif, kemampuan memecahkan masalah secara kreatif (creative problem solving), pembelajaran berbasis masalah, konsep dan pendekatan "limit to reach unlimited (dalam keadaan terbatas dapat melahirkan karya luar biasa)" menjadi signifikan dalam mengembangkan pembelajaran kreatif dan menfasilitasi pembentukan warga bangsa yang kreatif.

\section{Apa kreatif atau kreatifitas?}

Kreatif merupakan fitrah yang dianugrahkan Tuhan kepada setiap individu insan. Sayang, tidak semua individu manusia dapat mengembangkan potensi kreatif secara optimal. Pola didik orang tua/guru terhadap anak atau peserta didik yang tidak tepat alias keliru, lingkungan keluarga atau rumah dan sekolah yang kurang/tidak mendukung atau tidak memberi anak atau peserta didik peluang menjadi seseorang kreatif merupakan faktor penghambat.

Dalam pustaka psikologi terdapat lebih dari 60 (enam puluh) ta'rif atau pengertian kreatif. Kata kreatif dalam bahasa Latin creatus, secara harfiah berarti to have grown (telah atau menjadi tumbuh atau berkembang), dan créativité dalam bahasa Perancis. Istilah kreatif mencuat kembali setelah Perang Dunia II, yang sebelumnya kata-kata "invensi, discovery, dan imajinasi" lebih dikenal dalam masyarakat dunia. Mulanya kreatifitas hanya menjadi kajian atau riset di kalangan psikolog, sosiolog, teoritisi budaya yang terutama melakukan kajian (riset) tentang asal muasal pemikiran dan tindakan kreatif. Namun, belakang ini kre- 
atifitas menjadi perhatian para ekonom terutama yang melakukan riset tentang kreatifitas dalam kontek penumbuhan inovasi dan sumber kewirausahaan. Bahkan kini kreatifitas diyakini dapat menjadi faktor pendorong pertumbuhan ekonomi, kesejahtraan masyarakat dan pembangunan yang berkesinambungan (sustainable development) (Hui; Chung-hung; Mok, 2005; Howkin, 2002; UNDP, 2008).

Dalam bagian ini akan diuraikan pengertian kreatif, dimensi kreatif, unsur-unsur utama kreatif serta perbedaan antara berfikir kreatif dan berfikir kritis dan benang merahnya. Juga konsep orang kreatif, guru dan kepala sekolah kreatif serta anak kreatif akan dibahas. Uraian ini diharapkan dapat menjadi dasar dalam menetapkan batasan dan parameter kreatif dalam dunia pendidikan utamanya peserta didik dalam pelbagai jenjang pendidikan (PAUD, SD, SMP dan SMA).

\section{Pengertian kreatif}

Beberapa buku rujukan yang digunakan penulis menunjukkan pendapat atau pengertian yang beragam tentang kreatif dan keragaman pengertian tersebut sangat diumngkinkan dipengaruhi oleh sudut pandang dan latar belakang disiplin ilmu (kepakaran) seseorang. Kreavitas adalah proses melahirkan ide atau konsep baru atau sesuatu yang baru, atau mengintegrasikan ide atau konsep dengan penerapannya (validasi) yang menghasilkan produk orisinal dan baru (novelty) yang bernilai bagi pembuatnya dan dinilai bernilai atau bermanfaat bagi orang lain. Kreatif adalah kemampuan melahirkan sesuatu yang unik. Kreatifitas merupakan kombinasi antara kemampuan, keterampilan dan sikap. Kreatifitas adalah cara berfikir dan bertindak atau membuat sesuatu yang original (Mayaski, 2009). Gardner sebagaimana dikutip Fisher (2004) berpendapat kreatif merupakan kemampuan memecahkan persoalan, membuat produk dan melahirkan pertanyaan. Para ahli lainnya memahami kreatif sebagai state of mind dan proses imaginative yang menghasilkan produk original dan mempunyai nilai (Fisher, 2004). 
Kreatifitas mengandung nilai pendidikan bagi manusia karena kreatifitas akan menambah pengetahuan dan atau pengalaman bagi manusia. Kendati sesuatu yang baru pada awal dimunculkannya belum dihargai oleh orang lain atau berguna bagi fihak lain. Ketika anda melakukan tindakan kreatif atau memiliki ide kreatif, bisa saja anda secara langsung mendapat penghargaan atau pengakuan orang lain atau tidak. Karena apa yang anda (orang kreatif) miliki melampaui atau melebihi batasan pemahaman dan target yang ditetapkan orang lain (diluar jangkauan). Terkadang kelebihan seperti ini dianggap aneh oleh orang lain. Misalnya, anda mempunyai gagasan 'gila' atau formula atau resep sendiri yang sangat jauh berbeda dengan kebiasan orang lain untuk mengangkat sekolah anda ke tingkat unggul (excellence).

Kreatifitas merupakan hasil dari percampuran interaktif antar pengetahuan, kemampuan intelektual, gaya berfikir (thinking style), kepribadian, motivasi dan linkungan. Motivasi terdiri dua jenis yaitu intrinsik dan ekstrinsik. Motivasi intrinsik dan dorongan dari dalam mempunyai peran sangat penting bagi kelangsungan (sustainabilitas) usaha-usaha yang diperlukan untuk mencapai hasil atau produk kreatif (Ward, 2007).

Dalam kreatif terdapat kemampuan imajinatif atau imajinasi. Kegiatan imajinatif adalah proses melahirkan sesuatu yang asli. Dengan imajinasi kita dapat menghadirkan fikiran atau otak kita dalam imaji dan ide yang sebelumnya belum terpikirkan. Kreatif dapat juga berbentuk kemampuan memprediksi, merencanakan dan mengantisipasi akibat atau konsekwensi yang bakal muncul. Kreatif merupakan perpaduan antara percaya diri, kesadaran dan kompetensi yang dapat menunjang keberhasilan dalam kehidupan. Selain itu, kreatif merupakan adventurous thinking, yang dicirikan dengan keberanian melepaskan diri dari pakem [out of the box], terbuka terhadap pengalaman baru dan membuka diri terhadap pilihan atau alternative (Fisher, 2004).

Kreatif atau kreatifitas tumbuh melalui proses sebagai berikut: 
- Pertama kreatif diwujudkan melalui melahirkan sesuatu. Pada tataran yang sangat sederhana kreatifitas berwujud membuat, membentuk atau melahirkan sesuatu.

- Kedua kreatif diwujudkan dengan kemampuan menghasilkan sesuatu yang bervariasi [diferensiasi]. Mengulangi apa yang sudah dilakukan tidak termasuk dalam kategori kreatif. Seorang guru kreatif, misalnya, tidak hanya mengulangngulang model pembelajaran yang dinilai efektif, namun akan berusaha membuat variasi atau mengembangkan model pembelajaran yang dipratekan. Guru kreatif selalu melakukan refleksi terhadap yang dilakukan di kelas (pembelajaran) dan mengekplorasi prosesnya guna memperoleh pengetahuan dan cara-cara baru untuk pengembangan pembelajaran. Guru kreatif akan menjadikan pengembangan kreatifitas dan menumbuhkan rasa percaya diri di kalangan peserta didik bahwa mereka akan dapat berhasil dalam pembelajaran sebagai dasar (parameter) penilaian sekolah (bermutu atau efektif). Juga untuk menjadi seseorang (guru) kreatif diperlukan keberanian mengambil resiko karena apa yang ia miliki (gagasan, sikap, tindakan atau produk) berbeda dengan mainstraim yang ada.

- Ketiga, kreatif diwujudkan dalam originalitas [keaslian]. Yaitu sesuatu yang dilahirkan seperti gagasan, produk dan amaliah menjadi kejutan (temuan yang fantastik). Kita tidak akan disebut kreatif, apabila kita mengerjakan sesuatu dengan cara yang sama. Namun apabila kita melakukan atau memiliki pemikiran yang belum dilakukan dan dipikirkan orang lain, atau dinilai original, maka apa yang kita miliki dan lakukan merupakan kreatif sejati. Dengan kata lain, suatu tindakan disebut kreatif apabila melahirkan sesuatu yang baru (novel), asli atau unik (Starko, 2010; Fisher \& Williams, 2004).

Dari uraian tersebut diatas, kita dapat memilah kreatif atau kreatifitas dalam 3 (tiga) dimensi sebagai berikut:

- Pertama, berfikir kreatif yaitu melahirkan gagasan, konsep, 
harapan, tujuan baru serta pemahaman baru terhadap masalah (Lebih lanjut akan dibahas dalam sub bagian berfikir kreatif dan berfikir kritis).

- Kedua, sikap atau prilaku kreatif (creative behavior) yaitu sikap yang mendukung atau menfasilitasi proses kreatif seperti percaya diri. Prilaku kreatif merupakan fondasi berfikir kreatif dan amaliah kreatif. Oleh sebab itu, prilaku kreatif atau lebih dikenal dengan "prilaku konstruktif (constructive behavior)', mempunyai peran utama atau menjadi pendorong utama terhadap lahirnya pemikiran dan tindak kreatif.

- Ketiga, tindakan atau amaliah kreatifyaitu melakukan sesuatu yang baru (pengetahuan dan keterampilan) atau melahirkan produk satu-satunya pada waktu itu atau sesuatu yang sama sekali baru di masyarakat atau di dunia (Craft, 2005 ; Fisher \& Williams, 2004).

Ada tiga kriteria yang dapat dijadikan dasar untuk menilai sesuatu itu kreatif atau kreatifitas yaitu orisinalitas (keaslian), novelty dan appropriateness (ketepatan atau kegunaan). Sesuatu dikatakan kreatif apabila orisinal dan baru (novel) sebagaimana diungkapkan dimuka. Ketepatan atau sering disebut dengan relevansi merupakan kriteria ketiga (Starko, 2010) yang diterjemahkan dalam "manfaat atau kegunaan" dalam kontek positf [etika]. Bagi praktisi profesional, kreatifitas didefiniskan dengan "membuat sesuatu yang baru (novel), bermanfaat yaitu memungkinkan seseorang mendapatkan solusi inovatif atau unik" (Weintraub, 1998). Kreatifitas merupakan usaha yang bertujuan menjadikan sesuatu lebih baik dan berarti serta lebih indah. Kriteria tersebut perlu dilihat dari kontek budaya dan siapa yang menjadi subjek kreatifitas tersebut ketika seseorng menilai kreatif. Oleh sebab itu, ketika kita menilai kreatifitas seorang anak, misalnya, kita perlu menetapkan berdasarkan kriteria tertentu, yakni, perkembangan atau pertumbuhan anak, juga lingkungan sosio kultural sekolah dan masyarakat. Seorang anak dinilai kreatif apabila ia mampu menyampaikan suatu gagasan 
atau usaha memecahkan suatu masalahnya (Starko, 2010). Dalam suatu lingkungan yang diwarnai budaya paternalistic secara dominan, keberanian mengajukan pertanyaan kritis terhadap orang yang dianggap mempunyai otoritas atau tokoh merupakan wujud kreatif.

\section{Unsur-Unsur Utama Kreativitas}

Dalam kreatifitas terdapat beberapa elemen utama, yaitu: Pertama motivasi, yakni sesuatu ysng diinginkan dan tujuan dari yang dilakukan. Motivasi diperlukan untuk memberikan nilai terhadap usaha kreatif. Kreatifitas seseorang perlu diberi asupan [intake] berupa dorongan internal dan eksternal. Meski demikian motivasi dari dalam (intrinsik) mempunyai peran lebih (kuat) dalam mewujudkan kreatifitas. Kedua Inspirasi yakni diinspirasai oleh sendiri atau orang lain. Kreatif pada satu sisi dimulai dengan keingintahuan dan pada sisi lain dapat mengembangkan keingintahuan, melahirkan input baru (segar) dan memperkaya pengetahuan. Oleh sebab itu, menumbuhkan keingintahuan kepada anak-anak merupakan langkah awal menuju kehidupan yang kreatif. Ketiga adalah gestation [pengembangan] yakni memberi kesempatan [peluang] untuk memunculkan ide kreatif. Insight dan intuisi berhubungan dengan kreatifitas. Creative insight acapkali terlahir melalui proses yang tidak disadari dan berada dibawah kesadaran. Keempat collaboration, yakni dukungan dari mitra belajar atau masyarakat. Seseorang akan lebih kreatif apabila ia mendapat dukungan dari orang lain (Fisher \& Williams, 2004).

Sementara itu, Cropley (1997) menyebut 4 (empat) hal yang diperlukan untuk mendorong potensi kreatif muncul (aktual), yaitu: Pertama, seseorang memiliki pengetahuan dalam bidang tertentu yang diperoleh, misalnya, melalui penerapan conventional learning skills. Ini merupakan prasyarat bagi seseorang untuk menjadi kreatif. Kedua, ada bakat atau talenta. Talenta adalah kombinasi antara sensori, motor dan kemampuan intelektual yang menyebabkan seseorang dapat menghadirkan 
Pengembangan Daya Kreatif (Creative Power) Melalui Dunia Sekolah

kemampuan atau keterampilan yang luar biasa. Ketiga, usaha besar (great effort) dilakukan untuk menghasilkan produk. Seorang kreatif memiliki motivasi tinggi. Dengan motivasi tinggi, seorang kreatif terdorong mempunyai kepercyaan diri tinggi bahwa ia akan dapat mencapai tujuan atau maksud yang ingin dicapai (expectation of mastery). Motivasi tinggi dan percaya diri melahirkan sifat "lapar atau haus" akan pengalaman atau obsesif dengan ide atau tugas. Keempat, kesempatan yang tersedia. Potensi kreatif seorang akan muncul (actual) apabila seseorang diberi kesempatan.

Dari Cropley ada 3 (tiga) hal atau komponen yang dapat memperkaya pandangan Fisher dan Williams, yaitu (a) pengetahuan, (b) talenta) dan (c) usaha keras atau maksimal untuk mewujudkan potential kreatif (menjadi actual).

\section{Jenis Kreatifitas}

Ada beberapa jenis kreatifitas, yaitu fluid, crystallized, mature dan eminent. Fluid creativity salah satu jenis kreatifitas yang ada pada setiap orang dan menunjuk kepada tindakan yang dasar (sederhana), seperti menulis kalimat sederhana. Kemampuan kreatif ini berlangsung tidak lama. Crystallized creativity sama dengan kemampuan memecahkan masalah. Kemampuan kreatif ini berragam tergantung pada kompleksitas masalah yang akan dipecahkan. Mature creativity dapat dilihat dalam menangani persoalan yang komplek dengan originalitas, yang biasanya memerlukan keahlian yang dalam tentang masalah yang digarap atau dihadapi. Eminent creative berkaitan dengan atau mengaddress masalah yang cukup penting untuk melahirkan perubahan dalam bidang yang dikaji (shift in the discipline) (Starko, 2010; Weintraub, 1998).

Mayaski (2009) dan Craft (2002) membedakan dua jenis kreatifitas dengan label C (besar) dan c (kecil). Kreatif dalam $\mathrm{C}$ besar atau high creativity menunjuk kepada mewujudkan sesuatu yang betul-betul baru dan telah memperoleh pengakuan (social validation) bahwa yang dihasilkan itu memang baru sama 


\section{Fuad Fachruddin}

sekali dan melahirkan perubahan tingkat dunia. Contoh, temuan lampu. Kreatifitas dalam c kecil atau little creativity adalah ide atau produk baru hanya untuk orang yang bersangkutan. Kreatifitas ini digerakan oleh possibility thinking dan mengandung fleksibilias, intelligence dan novelty namun karya yang dihasilkan tidak mencapai derajat luar biasa. Misalnya, penggunaan finger paint berwarna.

\section{Siapa orang kreatif?}

Dalam membangun masyarakat atau bangsa, orang atau pemikir kreatif sangat diperlukan agar kita sebagai bangsa atau masyarakat dapat bersanding dan bertanding dengan bangsa lain. Juga menumbuhkan potensi kreatif (creastive power) pada masing-masing warga bangsa mempunyai arti penting untuk melahirkan seorang warga bangsa kreatif. Siapa orang kreatif? Secara sederhana Weintraub (1998) menyebutkan beberapa karakteristik orang kreatif yaitu orang yang anti meniru. Seseorang dinilai kreatif, apabila ia siap mencoba sesuatu yang baru atau sesuatu yang sama sekali baru. Seseorang kreatif memiliki kesediaan menanggung resiko [korban] apabila usaha yang dilakukan tidak berhasil alias gagal atau berani mengambil resiko (Stevenson, 2006). Seorang kreatif merasa antusias dan senang menggali sesuatu yang baru. Bagi seorang kreatif, resiko seperti kegagalan dapat menjadi ukuran kesenangan (Stevenson, 2006). Seseorang kreatif berusaha dengan baik mengkomunikasikan gagasan atau mencari masalah dan memecahkannya.

Bagi seorang pendidik, sikap-sikap atau karaker tersebut di muka perlu dilanjutkan atau ditumbuhkan dalam kelas sehingga kegiatan kreatif terjadi secara alami. Keberanian mengintroduksi pendekatan dan kegiatan kreatif memberi implikas terhadap teori dan praktek belajar di kelas (Starko, 2010). Individu kreatif akan menemukan cara baru untuk melakukan sesuatu atau mempunyai pemikiran berbeda. Seorang kreatif memiliki kemampuan mengeluarkan gagasan yang segar, terbuka dan bersedia melakukan perubahan. Dengan sikap atau karakter 
Pengembangan Daya Kreatif (Creative Power) Melalui Dunia Sekolah

seperti ini, seorang kreatif akan melahirkan atau menghasilan produk yang unik dan berbeda dengan karya yang dihasilkan oleh orang lain (Robert \& Harpley, 2007).

Ada beberapa ciri personal yang menunjukan seseorang kreatif. Ciri-ciri itu dikategorikan pada tiga besaran, yaitu ciri kognitif, kepribadian (personality) dan biographical events. Seorang kreatif dapat dibedakan dengan orang tidak kreatif dilihat dari beberapa hal seperti cara berfikir, nilai, temperament dan motivasi. Seorang kreatif akan menggunakan creative thinking [berfikir kreatif] untuk mengkomunikasikan ide dan memecahkan masalah. Dalam memecahkan masalah, seorang kreatif melakukan identifikasi masalah lantas menguraikannya ke jenis masalah secara khusus dan keperluan penyelesaian (pemecahannya). Dalam penemuan masalah, seseorang akan menemukan jenis kreatifitas (Starko, 2010). Kepribadian seseorang kreatif dapat dilihat dari kecerdasannya dalam menyelesaikan tugas atau pekerjaan yang sulit. Seorang kreatif selalu mencari perbaikan atau perubahan dan senang melakukan pencaharian gagasan, dan tidak suka mengikuti hal atau cara yang konvensional (Cropley, 1997).

\section{Siapa Guru Kreatif dan Pimpinan SekolahKreatif?}

Di muka telah disinggung karakter atau karakeristik guru kreatif, AI-Girl (2007) memberikan penjelasan tentang guru kreatif. Guru kreatif adalah seorang yang menguasai keilmuan (expert), memiliki otonomi di kelas (pembeljaran). Guru kreatif menetapkan tujuan, maksud, membangun kemampuan dasar (basic skills), mendorong pencapaian pengetahuan tertentu, menstimulasi keingintahuan dan eksplorasi, membangun motivasi, mendorong percaya diri dan berani mengambil risiko, fokus pada penguasaan ilmu dan kompetisi, mendukung pandangan positif, memberikan keseimbangan dan kesempatan memilih dan menemukan, mengembangkan pengelolaan diri (kemampuan atau keterampilan metakognitiv), menyelenggarakan pembelajaran dengan menggunakan berbagai teknik dan strategi untuk men- 
fasilitasi lahirnya tampilan [perwujudan] kreatif, membangun lingkungan yang kondusif terhadap tumbuhnya kreatifitas, dan mendorong imajinasi dan fantasi. Guru kreatif akan memberikan inspirasi kreatif kepada peserta didik (Fisher, 2004). Guru kreatif, menurut Cropley, 1997), fleksibel, luas pangaweruh dalam menyajikan materi dan menemukan cara penyajikan kepada anak (peserta didik). Guru kreatif mampu membangun hubungan yang menyenangkan dan dengan konsisten mengembangkan berfikir divergent di kalangan muridnya. Juga guru kreatif tidak bersikap manut tapi kritis dalam relasi dengan koleganya. Guru kreatif suka mengembangkan kritik terhadap dirinya, sikap dan perasaan tidak sepakat (kritis) terhadap system yang berlaku (Fisher \& Williams, 2004). Guru kreatif memberikan bimbingan dan mengarahkan peserta didik kepada tujuan (focus). Guru kreatif memilik sensitifitas dan kesadaran terhadap situasi yang ada. Guru kreatif akan melawan setiap sikap dan tindakan yang menghina atau mengecilkan peserta didiknya (Jeffrey \& Woods, 2003).

Guru kreatif akan muncul di suatu lingkungan termasuk lngkungan sekolah manakala kepemimpinan pendidikan (sekolah) kreatif tumbuh. Pemimpin sekolah yang kreatif akan memberikan peluang atau kebebasan dan restu kepada warga masyarakat sekolah (guru, peserta didik, staf) mengekspresikan kreatifitasnya. Pemimpin kreatif akan melibatkan berbagai fihak dalam dialog kreatif dan pembuatan keputusan yang kreatif. Pemimpin kreatif akan menjadi sumber inspirasi, memberi akses, waktu, sumber dan menciptakan lingkungan yang kondusif untuk melakukan eksperimen dan berbeda pandangan (konflik) (Fisher \& Williams, 2004).

\section{Anak Kreatif}

Menjadikan anak (peserta didik) kreatif merupakan salah satu tujuan dari pembelajaran. Kreatif merupakan bagian atau subset dari karakter positif dan karakter merupakan parameter mutu pendidikan dari dimesni nilai. Oleh sebab itu, penumbu- 
han kreatif merupakan kandungan dari konsep pendidikan yang perlu diwujudkan melalui pembelajaran. Cropley (1997) menyebutkan beberapa karakteristik anak sangat kreatif (highly creative children), yaitu memiliki motivasi berprestasi tinggi, cerdas, memiliki talenta dibanding peserta didik lainnya (peserta didik yang memiliki kemampuan biasa=bviasa). Anak kreatif biasanya memiliki (daya) imaji diri yang kuat dan sikap seperti ini dapat melahirkan prilaku atau tindakan yang dinilai negative, misalnya arogan, oleh sebagian orang. Anak-anak kreatif memiliki keingintahuan yang tinggi dan karakter ini dapat melahirkan sikap atau perilaku positive yaitu berani mengambil resiko. Keberanian mengambil resiko tidak hanya dalam pengerian fisik, juga dalam pengeterian intelektual dan sosial.

\section{Berfikir Kreatif dan Berfikir Kritis}

Berfikir kreatif dan berfikir kritis mempunyai pengertian dan fokus berbeda, namun keduanya sangat diperlukan dalam pembelajaran. Berfikir kreatif adalah kemampuan melahirkan gagasan, konsep, kehendak dan tujuan baru; pemahaman baru terhadap masalah yang dihadapi. Potensi berfikir kreatif dapat dikembangkan melalui pelbagai proses. Pengembangan berfikir kreatif merupakan cara yang ampuh yang dapat dilakukan dengan melibatkan anak-anak (peserta didik) dalam pembelajaran dengan menggunakan pelbagai cara dan pendekatan. Peserta didik yang terdorong berfikir kreatif akan memiliki motivasi dan percaya diri yang tinggi. Berfikir kreatif bertautan dengan pembuatan keputusan yakni kemampuan menetapkan nilai, gagasan dan produk. Berfikir kreatif di kalangan anakanak (peserta didik) dapat dilihat dari beberapa hal, misalnya, kemampuan anak melahirkan karya, menunjukan imajinasi dan originalitas dan menetapkan nilai, hasil atau karya dari yang dilakukan. Berfikir kreatif sangat penting untuk mewujudkan pembelajaran yang sukses dan keberhasilan dalam kehidupan. Dalam pembelajaran, berfikir kreatif merupakan salah satu kunci dari pembelajaran kontekstual yaitu sistem pembelajaran yang 


\section{Fuad Fachruddin}

dirancang membantu peserta didik memahami arti materi pembelajaran (akademik) dan belajar serta memiliki kemampuan menghubungkan pembelajaran dengan kehidupan sehari-hari mereka. Dalam pembelajaran kontekstual, peningkatan berfikir kreatif merupakan salah satu strategi untuk membantu peserta didik belajar (Fisher, 2004; Fisher \& Williams, 2004).

Ada beberapa muatan atau kandungan (property) dalam berfikir kreatif sebagaimana dijelaskan Cropley (1997), yaitu:

- Sensitivitas terhadap Masalah (Problem)- Seorang kreatif menunjukan kemampuan tinggi (piawai) dalam mengidentifikasi atau menetapkan masalah.

- Mendifinisikan kembali Masalah (problem)—Seorang kreatif mampu menguatkan (menjelaskan) kembali suatu masalah dengan istilah-istilah baru yang memberi insight baru dan pemahaman segar dengan pendekatan yang digunakannya.

- Penetrasi- Seorang kreatif selalu memiliki kemampuan menunjukan jantung atau titik utama suatu persoalan (problem) dengan mengabaikan detail informasi yang tidak relevan.

- Analysis dan Syntesis- Seorang kreatif memiliki kemampuan mengurai masalah kedalam bagian-bagian dan melihat hubungan antara elemen suatu masalah dengan pengalaman.

- Ideational Fluency - Setelah menunjukan masalah, menganalisisnya dan merumuskannya, seorang kreatif secara terampil melahirkan atau menghasilkan sejumlah gagasan yang relevan.

- Flexibility - Seorang kreatif biasanya menunjukan flexibilitas dan fluency. Poin ini mencakup kemampuan mengubah proses berfikir dan mencarikan pendekatan baru.

- Originality-Akhirnya, seorang kreatif akan menunjukan kemampuan yang tinggi dalam melahirkan sesuatu yang baru dan aneh (unusual).

Berfikir kritis juga perlu dikembangkan melalui pembelajaran, karena berfikir kritis merupakan bagian dari karakter 
[subset]. Berfikir kritis merupakan parameter mutu pendidikan dari dimensi nilai, sikap atau karakter. Selain itu, berfikir kritis merupakan bagian thinking skill yang menjadi bagian dari kemampuan kognitif. Ada beberapa pengertian atau definisi tentang berfikir kritis. Misalnya (a) berfikir kritis adalah kemampuan menimbang informasi dari berbagai sumber, memproses informasi dengan cara kreatif dan logis, mempertanyakan, menganalisis dan akhirnya memutuskan kesimpulan yang akan dipertahankan dan dijadikan pegangan. (b) Berfikir kritis adalah kemampuan menantang (chalange) gagasan atau teori. (c) Berfikir kritis adalah kemampuan mengembangkan argumen, mendekonstruksi ide atau mensintesasi pelbagai ide yang komplek dan memanfaatkan pelbagai cara untuk memperoleh kesimpulan yang sama atau berbeda terhadap isu yang sama. (d) Berfikir kritis adalah proses berfikir dalam 3 (tiga) dimensi yaitu depth, breadth dan time; bersikap obyektif dan tidak subyektif. Berfikir kritis bukan evalusi personal tapi refleksi yang diterapkan terhadap pemikiran atau teori orang lain. (e) Berfikir kritis adalah analisis terhadap suatu situasi berdasarkan fakta [bukti] untuk menetapkan suatu keputusan atau sampai kepada suatu keputusan (Dunn; Halonen \& Smith, 2008).

Dari pengertian tersebut kita menemukan hal-hal yang mendasar dari berfikir kritis. Berfikir kritis adalah aspek dari kegiatan berfikir. Berfikir kritis merupakan bentuk pembelajaran yaitu sarana untuk melahirkan pengetahuan baru dengan mengunakan the tools of manipulation of knowledge (seperti analisis, pemahaman dan sintesis). Fokus berfikir kritis adalah penilaian [the assessment] terhadap bukti yang ada untuk membuat suatu keputusan. Berfikir kritis biasanya berkaitan dengan masalah/ isu [subject matter] yang komplek dan memerlukan alternativ pendapat atau cara pandang; serta memerlukan keterlibatan seseorang secara mendalam dalam suatu masalah/isu [subject matter] (Moon, 2008: 23-24) .

Refleksi merupakan bagian dari proses berfikir kritis. Refleksi menunjukan sederet kemampuan berfikir (thinking skills) yang memadukan intellectual focus, motivasi dan keter- 
libatan dalam gagasan baru. Kemampuan berfikir mencakup kemampuan mengenal pola-pola; memecahkan masalah dengan cara praktis, kreatif atau ilmiah; terlibat dalam nalar psikologis dan mengadopsi berbagai cara pandang [perspektif] ketika seseorang yang memiliki kemampuan berfikir kritis menngevaluasi ide atau isu (Dunn; Halonen \& Smith, 2008).

Mengajar peserta didik berfikir kritis dalam kelas (pembelajaran) dan di luar kelas akan memperbaiki kemampuan mereka mengamati, menyimpulkan, mempertanyakan, mengembangkan ide baru dan menganalisis argumen. Dalam pembelajaran, tujuan pembelajaran berfikir kritis adalah memperbaiki kemampuan para peserta didik dalam menguraikan, memprediksi, menjelaskan dan mengontrol prilaku. Para guru memerlukan alat-alat yang relevan dan strategi pembelajaran yang dapat meningkatkan kemampuan peserta didik dalam berfikir kritis (Dunn; Halonen \& Smith, 2008). Berfikir kritis dapat ditumbuhkan atau dikembangkan di kalangan peserta melalui berbagai kegiatan, misalnya murid diberi tugas mengevaluasi obyek, mengembangkan argumen (Moon, 2008: 23).

Berdasarkan uraian tersebut, dapat disimpulkan tentang perbedaan antara berfikir kreatif dan berfikir kritis (Lihat Figure 1).

\section{Unsur-Unsur Utama (Key Components of Creativity)}

Kreatifitas mengadung beberapa elemen utama, yaitu: Pertama motivasi, yakni keinginan atau hasrat untuk mencapai sesuatu dan memiliki tujuan dari suatu perbuatan atau tindakan yang dilakukan. Motivasi diperlukan untuk memberikan nilai terhadap usaha kreatif. Kreatifitas seseorang perlu diberi asupan [intake] berupa dorongan internal dan eksternal. Kedua Inspirasi yakni inspirasi yang lahir dari dirinya atau melalui orang lain akan mendorong lahirnya kreatifitas. Kreatifitas dapat mengembangkan keingintahuan, melahirkan input baru (segar) dan memperkaya pengetahuan. Menanamkan keingintahuan kepada seseorang seperti peserta didik merupakan langkah awal menuju 
Pengembangan Daya Kreatif (Creative Power) Melalui Dunia Sekolah

\begin{tabular}{ll}
\hline \hline Berfikir Kreatif & \multicolumn{1}{c}{ Berfikir Kritis } \\
\hline Syntesa & Analysis \\
\hline Divergen & Convergen \\
\hline Lateral & Vertikal \\
\hline Possibility & Probability \\
\hline Imajinasi & Keputusan /penilaian (judgment) \\
\hline Hypothesis forming & Hypothesis testing \\
\hline Subjektif & Objektif \\
\hline Suatu jawaban (indefinite) & Satu jawaban (pasti/definite) \\
\hline Otak kanan & Otak kiri \\
\hline Terbuka (open-ended) & Tertutup (closed) \\
\hline Asosiatif & Lurus (linear) \\
\hline Spekulasi & Nalar (reasoning) \\
\hline Intuitiv & Logis \\
\hline Yes and & Yes but \\
\hline
\end{tabular}

Figure 1: Perbedaan antara Berfikir Kreatif dan Berfikir Kritis

kehidupan yang lebih kreatif. Ketiga adalah gestation [pengembangan] yakni memberi kesempatan untuk memunculkan ide kreatif. Insight dan intuisi berhubungan dengan kreatifitas dan memerlukan waktu untuk mewujudkan kreatifitas. Creative insight acapkali terlahir melalui proses yang tidak disadari dan berada dibawah tingkat kesadaran. Keempat collaboration, yakni dukungan dari mitra belajar atau masyarakat. Seseorang akan lebih kreatif apabila ia mendapat dukungan dari orang lain (Fisher \& Williams, 2004).

Berdasarkan uraian tersebut kita dapat menyimpulkan kreatif dapat diwujudkan dalam bentuk prilaku (creative behavior), berfikir (creative thinking) dan tindakan yang termasuk dalamnya product (denga kata lain creative action mencakup proses dan produk). Creative behavior merupakan unsur utama yang dapat melahirkan creative thinking dan creative act termasuk creative product. Ada beberapa parameter yang menunjukkan prilaku atau sikap kreatif (creative 
behavior), yaitu : (1) memiliki rasa ingin tahu yang tinggi, (2) memiliki motivasi berprestasi, (3) memiliki intuisi, (4) berpikir divergen, (5) berpikir kritis, (6) mencoba hal-hal baru, (7) berani menanggung resiko atas kegagalan, (8) kemampuan menentukan cara dan pilihan yang tepat (appropriates), (9) produktif, (10) selalu tidak puas terhadap yang dihasilkan, (11) mengkombinasi berbagai hal dan bentuk menjadi sesuatu yang baru, (12) memodifikasi dari sesuatu yang ada, (13) mencipta suatu ide atau karya yang baru sama sekali, (14) dapat menerima perbedaan, (15) setiap masalah dicari akar permasalahnnya dan tidak menimbulkan masalah baru, dan (16) bekerja dengan benar dan tenang dalam keadaan tertekan.

Berdasarkan tabel pada Figure 1 tentang "Perbedaan antara Berfikir Kreatif dan Berfikir Kritis" kita dapat menjabarkan 11 (sebelas) unsur dan merumuskan parameter untuk melihat kreatif dalam dunia sekolah. Begitu juga untuk "Tindakan kreatif" kriteria original, novelty dan relevan dalam ukuran-ukuran (parameter) pokok (core parameters) yang sesuai tingkat perkembangan peserta didik. Keadaan sosio-kultural lingkungan sekolah dan masyarakat perlu dikaji dan hasil kajian tersebut menjadi masukan untuk parameter utama tindak kreatif (creative act).

\section{Bagaimana menumbuhkan kreativitas?}

Bagian ini akan membahas hal-hal yang perlu diperhatikan dalam menumbuhkan dan mengembangkan potensi kreatif atau modal kreatif yang ada di masyarakat sekolah (peserta didik, guru dan manajmen). Indonesia yang terbentang luas memiliki keragaman latarbelakang sosio-ekonomi dan kultural. Juga lembaga pendidikan per jenjang yang ada di masing-masing daerah memiliki persoalan atau tantangan berbeda yang antara lain lantaran sumber-sumber yang dimiliki masih berbeda. Kesemuanya dapat memberi pengaruh terhadap pengembangan kreatifitas pada masing-masing satuan pendidikan--bentuk dan pendekatan pembelajaran serta evaluasi pembelajaran kreatif. 
Pengembangan Daya Kreatif (Creative Power) Melalui Dunia Sekolah

Oleh sebab itu, kajian secara cermat terhadap kekhasan masalah pada masing-masing jenjang pendidikan di masing-masing daerah sangat penting.

Misalnya, di Papua atau Kalimantan, khususnya di beberapa daerah pedalaman, anak-anak mengalami kesulitan mendapatkan alat tulis seperti pinsil. Ketika anak-anak tersebut bermain-main sambil membakar ikan, mereka akan mendapat inspirasi melahirkan ide kreatif dari arang yang ditinggalkan dari pembakaran ikan. Misalanya, mulanya secara iseng mereka menggoreskan arang bekas kayu pembakar ikan pada kayu atau kertas bekas atau tanah, lantas mendapatkan goresan hitam. Dari goresan hitam, ide atau gagasan muncul pada fikiran mereka untuk memfungsikan arang sebagai alat tulis (pinsil). Akhirnya anak-anak tersebut belajar menulis dengan pinsil buatannya sendiri. Lain halnya dengan anak-anak diperkotaan yang dalam lingkungannya peralatan elektronik tidak menjadi seuatu yang aneh, akan memiliki ide lain atau berbeda dengan teman-teman mereka di pedalaman Papua dan Kalimantan. Anak-anak di perkotaan akan membuat game pembelajaran yang dapat digunakan temantemannya melalui handphone sebagai perwujudan sikap dan tindak kreatif. ${ }^{2}$

Dari ilustrasi tersebut, kita dapat menyimpulkan bahwa dua kelompok anak (pedalaman dan perkotaan) secara fitrah memiliki potensi dan nilai kreatif yang sama. Hanya saja aktualisasi potensi dan nilai kreatif akan dipengaruhi oleh daya dukung lingkungan dimana anak-anak tersebut berada atau bermukiml. Kekhasan keadaan lingkungannya akan memberi warna terhadap karakter kreativitasnya. Selain itu, budaya yang ada dalam lingkungan anak-anak juga akan memberi corak kreatifitas-berfikir, bersikap dan bertindak.

Oleh sebab itu, bagaimana potensi kreatif yang dimiliki seluruh warga bangsa ini khusus peserta didik di pelbagai jenjang dan satuan pendidikan perlu diaktualkan secara optimal sehingga menjadi modal bangsa. Bagian ini akan membahas

2. Ilustrasi ini dari Sdr. Ihsan. 
beberapa hal yang berkaitn dengan pengembangan jiwa kreatif yaitu penciptaan atmosfir kreatif, pembelajaran kreatif dan penciptaan wahana apresiatif bagi kreativitas

\section{Syarat atau Kondisi yang perlu digarap}

Kreatifitas sebagaimana disebutkan dimuka mencakup tiga dimensi, yaitu prilaku kreativ (creative behavior), berfikir kreativ (creative thinking) dan tindak atau aksi kreatif (creative acts). Dimensi-dimensi kreatif tersebut dapat dikembangkan melalui institusi yang ada dalam masyarakat, seperti, sekolah. Potensi kreatif peserta didik, menurut Cropley (1997), dapat dikembangkan dengan menggunakan pelbagai cara atau pendekatan. Para guru, misalnya, membantu peserta didik melahirkan gagasan baru (invensi dan orisinal); menata kelas yang memberi banyak kesempatan peserta didik untuk memunculkan kreatifitas, bersedia menerima atau menghargai atau toleran terhadap prilaku kreatif; mengembangkan minat peserta didik berkreasi (kreatif) dan meyakinkan mereka bahwa mereka memiliki potensi menjadi insan kreatif. Juga para guru dapat mennstimulasi kreatifitas di kelas dengan menampilkan sikap dan prilaku kreatif (role model). Secara singkat dapat disimpulkan bahwa ada beberapa syarat yang diperlukan untuk menumbuhkan prilaku, sikap dan tindak kreatif di lingkungan sekolah.

Menciptaan Iklim atau lingkugnan Kreatif. Penciptaan lingkugnan kreatif dimaksudkan untuk menghadirkan suasana yang merangsang munculnya kreativitas yang dimulai smenjak awal proses pemuncul awal kreatif (bentuk sederhana) dan secara terus meneerus menfasilitasi penumbuhan kreatifitas hingga mencapai puncak kreativitas yang berwujud karya kreatif yang memiliki nilai dan kegunaan bagi orang banyak. Proses kreatif akan muncul pada saat seseorang berada dalam suasana (perasaan) aman, nyaman dan senang untuk menyampaikan pemikiran, mengajukan pertanyaan atau mempertanyakan sesuatu serta mengekspresikan gagasan-gagasan kreatifnya. Sebaliknya proses kreatif akan sulit berkembang apabila individu merasa 
tidak nyaman apalagi merasa sangat terancam atau tertekan. Sikap, prilaku dan tindakan orang-orang yang di lingkugnan dimana seseorang (anak), misalnya, merasa tidak aman, tidak nyaman, diabaikan, tidak dihargai, tertekan dan direndahkan dapat melahirkan ide. Iklim seperti ini tidak mendukung terhadap pengembangan daya kreaif (creative power) seseorng [anak] kreatif. Oleh karenanya, masyarakat termasuk keluarga dan institusi masyarakat seperti sekolah menduduki peran penting dalam menumbuhkan seseorang (anak) kreatif. Suasana yang kondusif tersebut dapat dihadirkan melalui optimalisasi fungsi dari tiga unsur utama, yaitu guru sebagai teladan kreatif (creative role model), lingkungan fisik dan lingkungan non fisik.

\section{Guru sebagai teladan kreatif (Role Model: The Creative} Teacher). Guru adalah kunci keberhasilan pendidikan. Paulo Freire (lihat karya seperti pedagogy oppressed) terobsesi pendidikan yang membebaskan jiwa manusia dari segala bentuk tekanan, kekangan apalagi penjajahan. Orang-orang yang terbebaskan jiwanya akan dapat mentransformasi dirinya menjadi insan kreatif. Untuk itu, guru yang handal yakni memilki pangaweruh yang dalam atau ilmu dan komitmen terhadap pemaratabatan warga masyarakat sebagai praksis dari konsep pendidikan sangat diperlukan. Guru, dalam kontek ini, dituntut dapat menjadi contoh seorang teladan kreatif (creative role model) yang mengembangkan sikap dan prilaku diri dan sejawatnya dengan antara lain mendorong "penciptaan" suasana kondusif bagi pengembangan kreativitas anak didiknya.

Beberapa hasil studi menunjukkan bahwa terdapat hubungan langsung antara keteladan kreatif dalam bentuk sikap atau berfikir kreatif (berfikir divergent) yang muncul dari sosok guru atau (meski mereka secara formal menyadari atau tidak disengaja) dengan tampilan berfikir divergent terhadap peserta didiknya. Begitu halnya, peserta didik yang memiliki kemampuan berfikir divergent tinggi akan memiliki prestasi sangat baik dalam pembelajaran. Hal ini juga mempunyai hubungan dengan guru yang memiliki kemampuan berfikir divergent tinggi, kendati keduanya-guru dan peserta didik - mungkin tidak begitu 
engeh dengan metoda atau pendekatan apa yang diterapkan untuk mendorong kemampuan berfikir divergent di kalangan individu-individu (anak-anak didik) berkembang. Para guru yang memiliki kemampuan berfikir divergent tinggi dapat mendorong pengembangan daya kreatif di kalangan peserta didiknya, meski para guru tidak membuat suatu upaya khusus dan disengaja untuk menumbuhkan kreatifitas. Oleh sebab itu, teladan prilaku kreatif dari para guru merupakan suatu faktor yang sangat kuat mendukung pengembangan kreatifitas di kalangan peserta didik (Cropley, 1997).

Keteladan para guru dapat diwujudkan dalam bentuk kemampuan ia mengembangkan komunikasi kreatif yakni menstimulasi pemikiran dan prilaku kreatif di kalangan anak-anak (peserta didik). Komunikasi kreatif mencakup paling tidak lima perilaku dalam komunikasi yaitu melayani, menstimulasi, menerima, mendukung dan mempromosikan. Melayani maksudnya adalah bersikap terbuka untuk melayani semua pertanyaan dan tantangan anak-anak kreatif. Guru melayani anak didik yang memerlukan respon, jawaban, bantuan dan bimbingan untuk menjalani suatu proses kreatif dengan sabar dan penuh antusias. Untuk menumbuhkan potensi kreatif peserta didik, guru (sebagai tauladan) dituntut untuk melakukan perubahan terhadap pendekatan dan komunikasi 'konvensional' terhadap anak didik. Para guru harus meninggalkan pendekatan lama yang tidak merangsang penumbuhan jiwa kreatif anak. Guru harus menghindari sikap negative, misalnya, memberi jawaban sekedarnya, tidak melayani pertanyaan, menutup komunikasi sebelum tuntas, mengkritisi yang sebenarnya meremehkan ketika peserta didik memulai suatu proses kreatif. Sikap dan prilaku komunikasi negatif seperti itu akan melahirkan suasana tidak mendukung (discourage) bahkan akan memupuskan potensi dan proses kreatif anak didik.

Lingkungan fisik. Lingkunganfisikmeliputilingkunganfisik sekolah dan luar sekolah. Ruang dan infrastruktur di lingkungan sekolah ditata menjadi lingkungan yang dapat menstimulasi siswa menjadi kreatif. Penataan lingkungan fisik menimbulkan 
suasana yang menstimulasi anak (peserta didik) membangkitakn sikap rasa ingin tahu yang tinggi (curious), berpikir kritis, berpikir kreatif bahkan juga berkreasi dalam segala bentuk dan jenis. Ruang dan atau infrastruktur di lingkungan luar sekolah, misalnya taman, gedung, lapangan, rumah, fasilitas publik, playground dan lain sebagainya, menjadi lingkungan yang membut peserta didik berinteraksi. Lingkungan luar sekolah ditata untuk menstimulasi kelima indera anak didik melahirkan sikap atau prilaku atau rasa ingin tahu yang tinggi (curious), berpikir kritis, berpikir kreatif bahkan membuat kreasi kreatif.

Lingkungan non fisik. Lingkungan yang kondusif akan menjadi enerji untuk memunculkan kreatifitas. Kreatifitas dalam kelas atau pembelajaran membutuhkan tidak hanya pengetahuan dan kemampuan guru dan peserta didik, juga lingkungan kelas yang dapat mengembangkan percaya diri dan keberanain. Para guru dapat memanfaatkan pengaruhnya untuk menciptakan suasana yang dapat melahirkan belajar kreatif. Untuk mewujudkan pembelajaran kreatif diperlukan kemampuan melahirkan gagasan dan kondisi emosional yang mendukung (memotivasi). Kondisi ini termasuk keinginan individu untuk memfungsikan diri secara kreatif. Lebih jauh lagi kreafitas memerlukan suatu lingkungan yang memberikan kebebasan kepada individu (anak didik) mengekspresikan ide, responsive terhadap gagasan baru yang memungkinkan anak didik dapat mengevaluasi secara bebas dari rasa ketakutan, ditolak atau dimaki. Untuk itu, guru dapat membantu menyingkirkan segala hambatan yang menghalangi kreatifitas muncul atau tumbuh yaitu membangun suatu suasana atau lingkngan yang memungkinkan anak didik dapat mengekspresikan idea atau fikirannya secara bebas (Crowley, 1997).

Lingkungan non-fisik tersebut meliputi berbagai kondisi sebagai berikut: Kondisi intrapersonal yang mendukung pewujudan berfikir kreatif dikembangkan ketika guru membantu anak didik memahami kemampuan berfikir divergent dan percaya diri, kendati ada gerakan kontra pengembangan kreatifitas. Kondisi emosional untuk memunculkan kreatifitas perlu 


\section{Fuad Fachruddin}

dikembangkan atau ditingkatkan ketika guru mendorong anak didiknya menyadari dan menghargai perasaan anak didik. Dalam waktu bersamaan, motivational climate dapat mendukung penumbuhan berfikir divergent ketika kecemasan menurun dan perasaan merasa terancam mulai tersisih. Salah satu caranya adalah meningkatkan hubungan interpersonal yang mendukung tumbuhnya berfikir kritis. Misalnya, guru mendorong anak didik kreatif menyajikan gagasan yang relevan dengan tujuan orang lain. Pada waktu bersamaan, anak didik dibimbing untuk dapat mengekspresikan kritik terhadap ide orang lain dengan cara yang konstruktif dan positif. Guru tidak hanya membantu kelompok anak didik yang kreatif juga membantu orang tua mereka dapat memahami bahwa anak-anak mereka dapat berbeda dibanding dengan anak-anak orang lain (dlihat dari kreatif). Guru hendaknya memainkan peran untuk mengatasi faktor-faktor yang akan mengahalangi lahirnya kemampuan berfikir divergent dengan (a) mengeleminasi sanksi negative terhadap fihak yang melawan fikiran divergen; (b) mengurangi perasaan khawatir "betul atau tidak betul" tentang ide, karya dan tindak individu; (c) mengatasi perasaan putus atas dan rasa teralinasi (atau merasa tidak berarti $=$ meaningless $)$ di kalangan mereka yang memiliki kemampun berfikir divergent yang tinggi pada awal mengetengahkan ide kreatif; (d) mencegah ejekan atau cercaan dari kelompok; (e) mengurangi kesalahfahaman dan rasa putus asa dengan orang tua. Iklim atau lingkungan non fisik yang mendukung kreatifitas tidak hanya memerlukan eliminasi unsur-unsur negative atau penghalang terhadap pemunculan atau pengembangan kreatifitas, juga menghadirkan faktor-faktor positif, misalnya (a) sensitif terhadap perasaan dirinya; (b) menaruh perhatian terhadap pengalaman sensori; (c) terbuka terhadap gagasan baru; dan(d) menghargai gagasan baru atau gagasan aneh (Cropley, 1997). 
Pengembangan Daya Kreatif (Creative Power) Melalui Dunia Sekolah

\section{Pengajaran dan Pembelajaran kreatif (Teaching \& Learning Creativity)}

Pembentukan perilaku kreatif termasuk berpikir kreatif, membutuhkan suasana/iklim yang memfasilitasinya. Fasilitas ini diawali dengan pemikiran tentang software seperti perancangan kurikulum, tujuan dan sasaran yang akan dicapai, metode dan teknik melaksanakannya serta evaluasi pelaksanaan. Selain itu untuk mewujudkan berfikir kreatifitas dalam aktivitas operasionalnya dibutuhkan hardware, berupa sarana pendukung fisik dan non-fisik. Sasaran dari pengajaran dan pembelajaran kreatif adalah melakukan perubahan (transformasi) terhadap sikap pasif ke bersikap, berfikir dan dan bertindak kreatif. Peserta didik diharapkan dapat mencapai perubahan sikap melalui proses pembelajaran yang tepat dilihat dari dimensi materi, pendekatan dan metoda pembelajaran. Seorang kreatif dicirikan dengan sejumlah karakter, misalnya rasa ingin tahu yang kuat untuk memperoleh jawaban akan segala hal yang diamati dan dipikirkannya, sikap dan pandangan terbuka terhadap segala fenomena yang diamati (open minded), tekun, motivasi intrinsik yang kuat dan memiliki daya tahan (endurance) untuk terus berpikir sampai mencapai hasil, misalnya, pemikiran atau gagasan atau produk nyata. Juga pesera didik memiliki karakter fleksibel dalam pengertian lincah berpikir dari satu dimensi ke dimensi pemikiran lainnya, lancar dan mudah menghasilkan ide yang mengalir, menggunakan cara berpikir lateral atau divergen.

Sikap kreatif merupakan proses mental yang dapat menghasilkan suatu karya kreatif atau inovatif yang bermanfaat dalam wujud benda atau non benda dengan syarat bahwa ada fasilitas lingkungan yang tersedia untuk penciptaan itu. Oleh karena itu, proses pembelajaran siswa diarahkan pada bermental kreatif, misalnya, mereka perlu diarahkan untuk selalu mengasah proses bermental tersebut, diberi kesempatan dan fasilitas untuk tumbuh kembangnya daya kreatifitas itu. Proses pembentukan ini dapat dilakukan dengan beberapa pendekatan dan konsep, sejalan dengan pengertian kreatif dalam kontek daya/kemam- 
puan yang ingin dicapai. Kurikulum pengajaran yang dirancang dapat merujuk kepada definisi yang dimaksud. Beberapa definisi yang digunakan adalah terciptanya ide baru yang orisinal yang terkadang ada kerancuan. Misalnya apakah ide yang diperoleh dari hasil modifikasi dari apa yang sudah ada sebelumnya dapat dikatakan orisinal/asli atau kreatif, suatu karya baru yang bermanfaat bagi kehidupan manusia, kombinasi ulang dari karya karya lain sebelumnya, dan lain sebagainya.

Perbedaan definisi dan pengertian ini membawa konsekwensi terhadap metode dan teknik dalam pembelajarannya. Metode dan teknik pembelajaran ini lebih dititik beratkan pada pembentukan "proses mental kreatif" atau proses kreatif atau prinsip-prinsip kerja kreatif. Prinsip kerja kreatif dicirikan dengan, misalnya, mengamati proses pembelajaran secara TOTAL yakni ketersambungn antara olah raga-olah pikir- olah rasa- olah hati; perjalanan dimulai dari ide/gagasan - melaksanakan (proses)- sampai hasil akhir; menggunakan LOGIKA RASA, IMAJINASI, INTUISI; pergumulan dengan gagasan yang bersifat abstrak sampai mewujudkan atau mengkongkritkan gagasan dalam bentuk karya; RELATIF(bahkan subyektif) sudut pandang atau perspektifnya. Kerja kreatif berorientasi pada PROSES yang berkesinambungan dan Hasil akhir merupakan kesimpulan sementara; dan terbentuknya KESADARAN BARU merupakan hal yang sangat penting. Pendekatan lain misalnya metode yang disebut COOPERATIVE-HOLISTIC- yang menggunakan pendekatan Neo Humanistic Education-LEARNING: yang mengikuti proses bertahap dimulai dari Orientasi, Eksplorasi, Partisipasi, Interaksi, Social Skill: Kepemimpinan.

Apapun pendekatan yang digunakan untuk menumbuhkan sikap dan motivasi berpikir dan berprilaku kreatif, penerapan berjalan berproses atau bertahap sesuai dengan perkembangan anak didik menurut jenjang pendidikan. Bertahap juga dimaksudkan sebagai pembentukan sikap yang dimulai dari pembentukan prilaku atau sikap kreatif sampai dengan bertindak kreatif dan menghasilkan produk kreatif. 
Pengembangan Daya Kreatif (Creative Power) Melalui Dunia Sekolah

Metode dan teknik pengajaran dan pembelajaran ini harus pula didukung dengan beberapa persiapan dan fasilitas agar tujuan "pendidikan kreatif" tercapai, seperti kondisi eksternal seperti wahana yang memicu proses kreatif, fasilitator yang dapat menggugah proses kreatif, sarana fisik dan non-fisik yang menstimulasi siswa untuk berpikir kreatif, networking atau jejaring yang memudahkan akses untuk bertindak kreatif, dukungan orang tua, dan sistem pendidikan yang memberdayakan pengajaran pembelajaran kreatif. Juga kondisi internal dalam proses mental siswa yang mencirikan adanya perasaan rileks-bebas-bermain, proses berpikir divergen, pembentukan sikap-minat-motivasi untuk berkreasi, dan munculnya kesadaran baru sebagai hasil proses belajar.

\section{Peningkatan Kreatifitasi di kalangan anak-anak}

Mayeksi (2009) menjelaskan bahwa dua hal yang perlu diperhatikan dalam menumbuhkan kreatifitas pada anak didik, yaitu perkembangan (developmental level) dan perbedaan individu. Tingkat perkembangan, tingkat pertumbuhan fisik, sosial, emosi dan intelektual. Perbedaan individu adalah tingkat perbedaan tentang kemajuan yang dicapai oleh masing-masing anak (peserta didik) dalam suatu area studi. Misalnya, apa yang menjadi kekhususan, minat, kemampuan, keterampilan yang telah berkembang; keadaan keluarga. Keduanya menjadi komponen praktek perkembangan yang tepat (Developementally appropriate practice). Maya membedakan pendekatan dalam mengembangkan kreatif anak pada usia dini dan usia kelas 4 atau 5 sekolah Dasar atau upper elementrary schools. Meski demikian untuk mengembangkan kemampuan kreatif diperlukan pengetahuan dan keterampilan. Misalnya, guru PAUD akan memberi pengetahuan dan keterampilan serta lingkungan yang mendorong tumbuhnya berfikir kreatif di kalangan anak didiknya. Peningkatan keatifitas pada anak-anak dilakukan melalui:

Bermain dan Eksplorasi. Misalnya, guru mengajak anak didik bermain computer yang terlebih dilakukan melalui 
eksplorasi untuk menemukan, misalnya, apa yang dapat dilakukan dengan computer. Lamanya eksplorasi tergantung kepada frekwensi eksposure anak didik berdasarkan kurikulum. Dibekali dengan keterampialan, anak-anak didik merasa enak menggunakan mouse, misalnya, lantas mereka benarbenar mulai memainkan computer. Dengan cara itu, anak didik mendapat pengetahuan dan keterampilan melalui pengalaman formal. Anak-anak mengeksplorasi dan bermain dengan bahan atau materi di lingkungan dan kegiatan tersebut dan kegiatgan tersebut membentuk 'the brain' (Coleman, 1995).

Peneriamaan secara positif (Promoting Creativity through Positive Acceptance). Penerimaan positive terhadap anak didik dilakukan dengan antara lain, guru menunjukan secara terbuka kepada anak didik bahwa prilaku ingin tahu, eksplorasi dan prilaku sejati mempunyai arti penting. Guru memberi peluang kepada anak didik ketika anak-anak didik melakukan kegiatan yang menarik dan menjadi minat mereka. Guru membiarkan anak didiknya melakukan kegiatan sampai mereka merasa bahwa pekerjaan sudah selesai atau rampung. Guru membiarkan atau memberi kesempatan anak didiknya memikirkan cara melakukan sesuatu apabila mereka memilih membuat sesuatu tindakan. Menciptakan suasana rilek juga dapat dilakukan oleh guru. Guru mendorong anak didiknya mengira atau menerka sesuatu terutama ketika jawaban yang dilontarkan masuk akal (Mayeski, 2009).

Meningkatkan kreatif anak didik pada usia kelas besar SD (Upper elementary grades): Untuk mendorong tumbuhnya kreatifitas di kalangan anak didik pada kelas besar SD, guru dapat menempuh beberapa cara, misalnya, memberi imbalan yang nyata, menghindari situasi kompetisi;mengarahkan murid dapat mengenali kekuatan dan kelemahan mereka; mendorong anakanak didik memantau karya mereka; menumbuhkan motivasi internal di kalangan anak didik sehingga mereka menyadari minat masing-masing individu dan masalahnya, membangun percaya diri dengan menegakan keadilan dan apresiasi terhadap talenta dan keunggulan mereka yang unik. Guru mendorong 
Pengembangan Daya Kreatif (Creative Power) Melalui Dunia Sekolah

anak diidk menjadi pembelajar aktif dan mandiri. Guru memberi kesempaan yang cukup memadai kepada anak didik memainkan pelbagai bahan. Juga guru menunjukan penghargaan atau penilaian terhadap kreatifitas anak didik. Kesemuanya merupakan cara yang ditempuh untuk menumbuhkan kreatifitas peserta didik. Selain itu, guru dapat menjelaskan tujuan adalah mengembangkan berfikir kreatif (Mayeski, 2009).

\section{Mengembangkan Kreatifitas Anak-Anak melalui pembelajaran (Kurikulum).}

Ada beberapa prinsip yang perlu dipertimbangkan dalam hal ini yaitu: Kurikulum semestinya dirancang secara tepat untuk anak, memilih materi dan kegiatan yang bermanfaat dan relevan dengan kebutuhan anak. Juga guru menyiapkan berragam bahan yang dapat mendorong mengeksplorasi kreatif anak yakni memberikan waktu yang memadai kepada anak-anak untuk menetapkan apa yang akan dilakukan. Guru mempertimbangkan tipe atau gaya belajar dan kecerdasan berganda (multiple). Para anak didik didorong untuk berfikir divergen dan memiliki rasa ingin tahu yang tinggi. Guru menyiapkan sistim point untuk setiap pertanyaan anak yang menunjukan keingintahuan. Juga guru memberikan kesempatan banyak kepada anaka-anak didik untuk berinterkasi dan berkomunikasi dengan temannya dan orang dewasa dalam atmosfer yang merasa diterima. Pembelajran yang mendorong tumbuhnya kreatif dilakukan dengan berbagai bentuk, misalnya, melalu eksperimen pelajaran sain dan diskusi suatu isu (Mayesky,2009).

Kurikulum terpadu (Integrated Curriculum). Kurikulum dirancang berdasarkan tema atau proyek kelas. Unit pembelajaran terdiri dari kegiatan pembelajaran berseri yang dirancang berdasarkan topik besaran yang melibatkan seluruh kelompok. Topik ini mengandung unit area pembelajaran seperti membaca, matematik, sain, ilmu sosial dan menyiapkan atau memberikan topik dan framework perencanaan kegiatan untuk anak didik. Anak didik secara keseluruhan mencoba mengalami (Mayesky, 
2009).

Differentiated Instruction (DI). DI adalah cara berfikir atau suatu perspektif tentang pembelajaran yang didasarkan kepada prinsip atau pandangan sebagai berikut: (a) Anak dalam usia sama (seusia) memilki perbedaan dalam beberapa hal yaitu kesiapan belajar, minat, gaya belajar [styles of learning], dan pengalaman. (b) Perbedaan tersebut mempengaruhi apa yang perlu dipelajari anak didik dan tugas utama guru dan sekolah adalah memaksimalkan kemampuan setiap anak didik. (c) Juga DI merupakan usaha perbaikan untuk mencapai mutu tinggi kurikulum dan pembelajaran dan anak didik terlibat dalam menetapkan tujuan. (d) Kurikulum mempunyai hubungan dengan pengalaman dan minat anak didik. Oleh sebab itu DI dimaksudkan untuk memaksimalkan pertumbuhan anak dan membantu anak mencapai suatu kemajuan (Mayesky, 2009).

Penciptaan Wahana Kreatif. Proses pengajaran dan pembelajarn semata tidak cukup untuk membentuk dan menumbuhkembangkan sikap dan prilaku kreatif pada anak didik. Oleh sebab itu, diperlukan sarana yang dapat secara sinambung memelihara dan mempertahankan sikap dan motivasi anak didik berproses kreatif secara ajeg. Penciptaan wahana kreatif menjadi stimulan yang selalu hadir dan menggugah siswa untuk berkreasi. Guru memainkan peran sebagai sponsor kreatifitas yaitu guru melakukan kegiatan yang mendorong anak didik terlibat melalui pemberian hadiah terhadap suatu prilaku kreatif, memberikan kesempatan untuk mencapai prestasi (sukses); menfasilitasi tumbuhnya kemampuan berfikir divergent dengan memberikan kesempatan kepada anak didik mengkomunikasikan ide mereka kepada orang kain dan mengakui atau menghargai gagasan kreatif atau kemampuan berfikir divergent. Guru dapat memberikan kesempatan yang lebih leluasa kepada anak didik untuk "bermain" dengan masalah, material dan ide atau menyuntik fantasi sebagai sumber ide. Hal ini dapat dilakukan melalui kegiatan-melakukan science fair untuk mengekhibisikan mesin-mesin yang akan diproduksi atau dibutuhkan masa mendatang, mengorganisasi festival drama dengan tema-tema masa mendatang dan fantasi 
atau menyuruh anak-anak didik mendeskripsikan kejadian histories yang bakal terjadi (Cropley, 1997).

Penyediaan institusi dan Event Kreatif. Guna menciptakan Wahana Kreatif. Selain sekolah, institusi lain yang memilki komitmen dan tanggung jawab untuk membangun suasana pendidikan kreatif bagi siswa diperlukan. Institusi ini tidak terbatas pada institusi dan lembaga pemerintah, namun juga harus diperluas dalam kontek pemberdayaan semua institusi di masyarakat agar tumbuh kesadaran pada mereka tentang arti atau pentingnya proses berpikir kreatif, sehingga proses berikutnya seperti melahirkan karya kreatif atau inovatif. Misalnya, dalam krastif ekonomi. Suciu Marta-Christina dari Bucharest Academy of Economic Studies, Faculty of Economics, Economics \& Economic Policies Department menyatakan bahwa prasyarat terbentuknya Ekonomi Kreatif adalah Urban Development dan Community yang mendukungnya. Sedangkan Florida (2005), dari university of Toronto menyatakan bahwa penciptaan Wahana Kreatif juga didukung oleh apa yang ia namakan "Creative Class", yang menurut pengamatannya dapat menjadi pendorong untuk pengembangan ekonomi kota-kota di Amerika pasca era industri. Tiga kelompok Creative Class disebutkan oleh Florida ialah Supercreative Core, Creative Professional dan Bohemian. Selain institusi dan Creative Class, institusi yang juga penting untuk pengembangan Wahana Kreatif adalah rumah/keluarga sebagai kelompok terkecil dalam masyarakat. Rumah atau keluarga seharusnya menjadi awal dari stimulasi proses pembelajaran kreatif bagi siswa yang dalam kelanjutan dan pengembangan akses hubungan berikutnya dengan institusi lain di luar rumah dapat diharapkan memperteguh sikap dan pola prilaku yang terbiasa bersikap kreatif.

Pemberian Penghargaan atas Kreativitas. Ajang lain yang tidak kalah pentingnya untuk membangun Wahana Kreatif adalah adanya perlakuan yang konsisten berupa penghargaan, pengakuan, pujian, terhadap karya kreatif mereka. Siswa yang secara konsisten mendapatkan pengakuan dan penghargaan yang proporsioanal terhadap hasil karyanya, utamanya yang 


\section{Fuad Fachruddin}

bernilai kreatif, merasa mendapatkan tempat bagi prestasinya, sehingga dapat menumbuhkan rasa percaya diri dan konsep diri yang positif. Selain itu juga akan terbentuk sikap dan prilaku selalu ingin berkarya, sikap optimis dan antusias bahwa ia bisa berprestasi dan prestasi itu diapresiasi secara terbuka. Perlakuan ini akan mempertahankan motivasi siswa untuk terus menrus berkreasi, sehingga pada akhirnya menjadi suatu kebutuhan dasar. Motivasi intrinsiknya menunjukan kemampuannya sebagai bagian dari kontribusi dan tanggung jawab pribadinya pada lingkungan di sekitarnya. Pemberian penghargaan ini menjadi tanggung jawab semua pihak di masyarakat, jadi bukan hanya tanggung jawab institusi tertentu. Semua pihak, institusi pemerintah dan swasta, kelompok atau pribadi, memiliki tanggung jawab yang sama untuk menciptakan Wahana Kreatif.

Penanam sikap menghargai atau apresiasi terhadap kreatifitas atau karya kreatif juga mempunyai kaitan dengan penanaman integritas diri (karya akademik). Misalnya, penanam apresiasi terhadap kreatifitas atau karya kreatif kepada peserta didik secara simultan menamkan sikap intoleransi teradap cheating atau plagiasi dalam karya akademik.

\section{Mengambil Hikmah Pengembangan Tradisi Kreatif}

Untuk mengembangkan tradisi kreatif di lingkungan lembaga pendidikan pada satuan pendidikan, perlu kiranya kita mengambil manfaat (hikmah) dari 12 (dua belas) kunci yang ditawarkan AI-Girl(2007) , yaitu:

Mendefiniskan kembali masalah. Yaitu mengambil suatu masalah dan menarik akar persoalannya. Mendefinisi ulang suatu masalah artinya membebaskan seseorang dari pakem (out of box). Proses ini merupakan bagian dari berfikir kreatif. Para guru dan orang tua dapat meningkatkan tampilan kreatif dengan mendorong anak-anak (didik) dapat merumuskan dan mendefinisi ulang masalah dan proyek mereka. Secara sabar orang dewasa membantu mendorong timbulnya berfikir kreatif di kalangan anak dengan membimbing anak-anak atau peserta 
Pengembangan Daya Kreatif (Creative Power) Melalui Dunia Sekolah

didik memilih topik untuk makalah atau presentasi, memilih cara menyelesaikan masalah dan memilih kembali atau menemukan pilihan yang lalu yang salah. Guru dan orang dewasa semestinya memberi keleluasan anak-anak didik mereka memilih topik tentang proyek yang akan dilakukan anak-anak. Persetujuan terhadap topik yang dipilih dan relevan dengan pelajaran, serta memberikan kesempatan kepada mereka melaksanakan proyek sampai mereka berhasil.

Mempertanyakan dan Menganalisis Asumsi. Orang kreatif akan mempertanyakan asumsi-asumsi dan mengajak orang lain melakukan serupa. Mempertanyakan asumsi merupakan bagian dari berfikir analitik yang didalamnya terdapat kreatifitas. Guru menjadi tauladan dalam mempertanyakan asumsi-asumsi dengan menunjukan bahwa ia faham atau tidak tahu apa yang menjadi dasar asumsi. Mempertanyakan asumsi akan memberi pelajaran kepada seseorang .

Jangan berfikiran bahwa ide kreatif dengan sendiri dibeli orang: Juallah Ide Kreatif. Ide kreatif biasanya dicurigai dan acapkali orang pada awalnya tidak percaya. Orang yang mengajukan idea kreatif dilihat dengan penuh kecurigaan dan ketidak percayaan. Mengapa demikian? Orang biasa merasa nyaman dengan cara dan tindakan yang dilakukan atau mereka berkepentingan dengan fikiran yang telah diagemnya. Oleh sebab itu mereka sulit keluar dari pemikiran yang ada dan menerima pemikiran baru. Jadi, anak-anak perlu belajar merayu orang lain menghargai gagasan mereka. Misalnya, anak-anak mendemonstrasikan proyek kelas untuk sain ke masyarakat.

Mendorong Timbulnya Gagasan. Orang kreatif menghadirkan gagasan kreatif. Lingkungan yang melahirkan gagasan adalah lingkungan yang kritis konstruktif, namun tidak seharusnya kritis destruktif. Oleh sebab itu, anak-anak perlu mengenal atau membanding ide-ide yang ada sehingga mereka menemukan ide yang lebih baik. Orang dewasa dan anak-anak bekerjasama menemukenali ide-ide kreatif yang akan disajikan. Guru tidak perlu mengkritik apabila gagasan yang disampaikan 
anak-anak tidak memiliki makna. Guru sebaliknya harus memberikan cara baru yang akan memberikan poin atau apresiasi terhadap kreatifitas. Anak-anak yang berhasil memunculkan ide perlu diapresiasi, terlepas apakah idea 'rendahan' atau tidak mempunyai kaitan. Guru hendaknya mendorong mereka mengidentifikasi dan mengembangkan gagasan yang terbaik ke proyek atau kegiatan yang bermutu tinggi.

\section{Ketahuilah bahwa Pengetahuan bagaikan Dua Sisi Mata} Pedang dan Gunakan secara tepat. Orang tidak akan menjadi kreatif tampa memiliki pengetahuan. Banyak anak memiliki ggasan yang kreatif menurut mereka namun tidak menurut disiplin ilmu karena orang lain memiliki gagasan yang sama sebelumnya. Mereka yang memiliki landasan pengetahuan yang lebih besar akan lebih tampak dan dihargai ketimbang mereka yang baru mempelajari dasar-dasar pengetahuan.

Mendorong Anak-Anak Mengidentifikasi dan Menyelesaikan Problem. Para guru menyiapkan anak-anak jenis-jenis pengalaman dengan menguraikan hambatan-hambatan yang tampak dalam kehidupan masyarakat ketika orang yang mencoba menjadi kreatif. Hal ini perlu diperkenalkan kepada anak-anak agar mereka tidak beranggapan bahwa hanya dirinya menghadapi hambatan. Guru harus memasukan ceritacerita yang tidak mendukung gagasan kreatif dan penerimaan yang dingin terhadap gagasan yang dinilai sangat baik. Guru dapat membantu dengan, misalnya, mengingatkan anak-anak bahwa banyak gagasan orang kreatif pada awalnya ditolak; juga membantu anak-anak mengembangkan rasa surprise terhadap tindakan kreatif.

\section{Mendorong/Mendukung Sikap Berani Mengambil} Resiko Secara Rasional. Orang kreatif berani mengambil resiko secara rasional dan melahirkan gagasan yang akhirnya orang lain memuji dan menghormatinya sebagai trend-setting. Terkadang dalam keberanian mengambil resiko, seorang kreatif melakukan kesalahan, gagal dan kehilangan muka. Kesemuanya merupakan bagian resiko yang harus dipikul. 
Pengembangan Daya Kreatif (Creative Power) Melalui Dunia Sekolah

Mendorong Toleran terhadap Ketidakjelasan/Yang Meragukan.Dalam kehidupan sering ditemukan masalah yang berada dalam wilayah abu-abu. Sementara kebanyakan orang berfikir hitam putih. Ide kreatif cendrung datang dalam bentuk serpihan dan potongan yang berkembang terus sepanjang waktu. Sewaktu ide tengah berkembang biasanya tidak menyenangkan, karena gambaran karya kreatif belum muncul secara utuh. Tampa adanya waktu atau kemampuan menolerir ambigitas, orang langsung melompat mencari jalan penyelsesaian secara pintas [tidak optimal].

Bantu Murid Membangun Percaya Diri. Dalam kehidupan acapkali orang atau kita sampai kepada titik perasaan bahwa tidak seorangpun mempercayai dirinya [diri kita]. Perasaan semacam akan ditemukan oleh setiap orang kreatif. Karena kerja-kerja kreatif acapkaii pada awalnya tidak mendapatkan penerimaan yang hangat dari lingkungan. Oleh sebab itu orang kreatif harus memiliki kepercayaan diri bahwa yang dilakukan memiliki arti.

\section{Bantu Anak-Anak menemukan apa yang mereka suka} lakukan. Guru hendaknya menbantu anak didiknya menemukan sesuatu yang mereka minati untuk menghasilkan karya kreatif yang terbaik. Orang-orang yang berprestasi atau melahirkan karya terbaik biasanya mereka mencitai apa yang dilakukan sepenuh hati. Membantu anak-anak mengungkapkan minat yang sebenarnya dengan cara, misalnya, guru meminta anak-anak didik mendemontrasikan talenta atau kemampuan mereka yang spesial di kelas dan menjelaskan apakah ia melakukan sesuatu kegiatan hanya sekedar hobi atau bukan, tidak masalah.

Ajari Anak-Anak penting menunda Kesenangan Diantara proses menjadi kreatif adalah mampu melakukan proyek atau tugas jangka panjang tampa mendapat penghargaan segera. Anak-anak didik harus memahami bahwa penghargaan tidak selamanya muncul segera dan mendapat manfaat. Pada umumnya mereka tidak mendapat penghargaan segera atas karya kreatifnya. Untuk jangka pendek atau sementara, biasanya kebanyakan 
orang acuh atau mengabaikan dan bahkwn menghukum orang kreatif.

\section{Menyiapkan Lingkungan yang Mendukung Peng-} embangan Kreatifitas. Ada beberapa cara yang dapat dilakukan guru untuk menciptakan lingkungan yang kondusif terhadap pengembangan kreatifitas. Cara yang paling ampuh adalah guru menjadi role model of creativity sebagaimana diungkapkan di muka. Anak-anak tidak menunjukan kreatifitas ketika mereka disuruh, namun mereka akan melahirkannya apabila diberi contoh (teladan) (ingat ungkapan "Sebuah teladan jauh lebih ampuh dari sejuta ungkapan). Sebagaimana kita ketahui bersama bahwa kebanyakan orang memandang Guru-- dirinya, fikiran atau ucapan dan tindakan-- sebagai contoh. Kreatifitas merupakan kegiatan manusia yang paling penting dan merupakan sesuatu yang sangat penting dan berkembang terus. Kreatifitas merupakan respon yang efektif dan berguna untuk melakukan perubahan evolutif. Pembelajaran kreatif akan mengangkat prestasi anak didik. Kreatifitas dalam dunia akademik akan menghasilkan manfaat output, proses yang memungkinkan survivalitas dan pertumbuhan. Berfikir kreatif akan menjadi predictor dari efektifitas guru (AI-Girl Tan (2007).

\section{Penutup}

Sebagai penutup tulisan ini mengingatkan bahwa penilain kretif bagian penting dari upaya untuk mengembangkan daya kreatif. Pembahasan ini merupakan ranah dari pakar psikologi. Penulis berlatarbelakang pendidikan (PhD) dalam konsentrasi "Social and comparative analysis in education" dan (MSc) dalam konstrasi "social development." Berdasarkan sumber rujukan yang digunakan dalam tulisan ini, penulis ingin mengajukan beberapaisu (identified issue) yang perlu mendapat perhatian dalam penilaian kreatifitas. Pertama, garapan studi kreatifitas. Kaufman et all (2008) menginngat 4 (empat) model P yaitu people (i) person, (ii) process, (iii) product dan (iv) press (lingkungan). Studi tentang orang kreativ (creative people) melihat karakteris- 
tik orang sebagai creator, yang isu kajian mencakup kepribadian, motivasi, kecerdasan, kecerdasan emosi dan pengetahuan. Kajian terhadap pengalaman aktul menjadi seorang kreatif merupakan ranah kajian proses kreatif (creative process), yakni alur seorang terlibat atau menjadi kreatif. Lingkungan rumah dan lingkungan keluarga memberi pengaruh terhadap pengembangan daya kreatif seseorang (creative press). Dengan kata lain, lingkungan dapat menjadi pendukung atau penghambat terhambat terhadap pengembangn daya kreatif seseorang. menjadi aktual. Creative product adalah sesuatu yang dihasilkan atau dibuat oleh seorang seperti barang atau benda, gagasan dan respon.

Kedua, ada beberapa alat evaluasi kreatifitas dilihat dari domain. Torrance (1966), misalnya, membuat Test of creative Thinking (TTCT) untuk melihat kemampuan berfikir divergen. Dalam evaluasi ini indikator yang diukur adalah berpikir divergen dan kemampuan problem solving yang dinilai dari skor Fluency, banyaknya gagasan yang dialirkan, Flexibility, lincahnya gagasan berpindah dari satu tema ke tema lain, keaslian dan keunikan gagasan (originality), dan pendalaman dan rincinya gagasan yang dapat diuraikan (elaboration). Guilford mengidentifikasi komponen utama dari karya [befikir] divergen yang telah menjadi tulang punggung beberapa riset dan penilaian (assessment) kreatifitas. Yaitu fluency (memunculkan atau melahirkan beberapa gagasan), flexibilitas (memunculkan atau melahirkan beberapa jenis gagasan yang berbeda dari cara pandang yang berbeda), originalitas (memunculkan atau melahirkan gagasan yang aneh atau tidak lumrah), dan elaborasi (menambah ide-ide untuk memperbaiki gagasan). Guilford identifikasi dua kategro kemampuan kreatif berfikir divergen dan transformasi, kemampuan memperbaiki yang dialami seseorang atau diketahui untuk melahirkan bentuk/gagasan baru (Starko, 2010). CAT (the Consensual Assessment Technique) adalah metoda yang digunakan untuk mengevaluasi produk kreatif. Para ahli membuat rating terhadap produk kreatif seperti puisi, koleksi barang dan lainnya (Kufman et all, 2008).

Evaluasi pembelajaran proses kreatif ditujukan pada dua 


\section{Fuad Fachruddin}

sasaran. Pertama, evaluasi proses menyangkut mental berpikir kreatif yang telah terbentuk melalui pembelajaran itu; dan kedua, hasil kreatifitas yang dapat berbentuk gagasan, sikap dan produk benda yang mungkin sudah final atau masih sementara. Evaluasi terkait proses mental yang terbentuk pada siswa dapat dilihat atau ditelusir dari ciri ciri perilaku sebagai berikut: apakah dalam anak (peserta) didik terbentuk sikap antusias/bersemangat untuk berkreasi, sikap bertanggung jawab akan hasil gagasan/kreasinya, peningkatan kemahiran/teknik berkreasi, penguasaan materi/ tema ajang kreasinya, sikap bereksplorasi, prilaku kerjasama yang kondusif dan efektif, optimalisasi kerja individual, tumbuhnya rasa percaya diri, dan keterbukaan dan kemauan untuk mempresentasikan hasil ("sementara").

Akhirnya, ada beberapa pertanyaan reflektif, misalnya sebagai: (a) guru atau pendidik apakah kita sudah menjadi guru kreatif? (a) kepala sekolah kita sudah menjadi kepala sekolah kreatif? (c) Pengawan pendidikan apakah kita sudah menjadi pengawas pendidikan yang kreatif? Otoritas pendikan di tingkat daerah kita sudah menjadi otoritas pendidikan kreatif?.

Kalau kita dalam peran-peran tersebut belum seperti yang diharapkan (kreatif). Apa yang dapat dilkukan agar kita. sebagai (a) guru, (b) kepala sekolah, (c) pengawas, (d) otoritss pendidikan tingkat daerah, dapat menilai sendiri apakah dirinya (guru) sudah melaksanakan pembelalajaran (pengajaran) secara kreatif dan atau dapat melihat apakah peserta didik mereka kreatif-berfikir kreatif, bersikap kreatif, membuat karya atau produk kreatif. (b) kepala sekolah dapat melihat dirinya sebagai pemimpin (kepala) sekolah kreatif, dapat menilai lingkungan sekolah kreatif dan guru kreatif; (c) pengawas dapat melihat dirinya sudah melakukan supervise secara kreatif dan menilai apakah guru-guru dan kepala sekolah kreatif; dan begitu seterusnya.

Dengan pertanyaan reflektif tersebut kita dapat memetakan diri kita masing-masing dalam posisi mana (kreatif atau belum) dalam melakukan peran-peran tersebut dan dapat melakukkan 
Pengembangan Daya Kreatif (Creative Power) Melalui Dunia Sekolah perubahan terhadap situasi yang ada agar ke depan kita sebagai individu atau warga bangsa menjadi warga bangsa kreatif yang dapat dan siap memberi kontribusi untuk kemajuan bangsa dan Negara. 


\section{BIBLIOGRAFI}

AI-Girl, Tan (2007) Creativity: A Handbookfor Teacher. New Jersey: World Scientific

Baker, Ronald J. (2008). Mind Over Matter: Why Intellectual Capital is The Chief Source of Wealth. New Jersey: John Wiley \& Sons, Inc.

Burnouf, Laura (2004) "Global Awareness and Perspectives in Global Education." Canadian Social Studies Volume 38 Number 3, Spring

Cohen, Robin; Kennedy, Paul (2000). Global Sociology. New York: Global Sociology.

Carnoy, Martin (1999), Globalization and Education Reform: What Planners Need to Know Paris: UNESCO

Craft, Anna (2005) Creativity in Schools Tensions and Dilemmas. USA, Canada: Routhledge

Cropley, Arthur J. (1997) More Ways Than One: Fostering Creativity. Norwood, New Jersey: ABLEX PUBLISHING CORPORATION

Dunn, Dana S; Halonen, Jane S. \& Smith, Randolph A (2008). Teaching Critical Thinking in Psychology: A Handbook of Best Practices. Oxford: Willey-Blackwell

Fisher, Robert (2004) "What is creativity?" in Robert Fisher \& Mary William (eds.) Unlocking Creativity: Teaching Across the Curriculum. London: David Fulton Publisher

Fisher, Robert; Williams, Mary (2004)Unlocking Creativity: Teaching Across the Curriculum. London: David Fulton Publisher

Fachruddin, Fuad (2010). Pendidikan Karakter: Beberapa Isu. Makalah. Seminar Internasional diselenggarakan oleh Program Pasca Sarjana (PPS) IAIN Raden Fatah Palembang bekekrja sama dengan Pemda OKU dan Pagar Aalam, 17 \& 18 Mei 2010.

Fachruddin, Fuad (2008). SBI (Sekolah Berstandar Internasional)/ Global School dan Internasionalisasi Pendidikan. Makalah. Panel Diskusi dalam Pameran Buku Nasional 29 Juni 2008, dimuat dalam surat Kabar Media Indonesia 
Pengembangan Daya Kreatif (Creative Power) Melalui Dunia Sekolah

Howkins, John (2002). The Creative Economy: How People Make Money from Ideas. England,New York: Clay Ltd.

Hui, Desmond; Chung-hung, NG; Mok, Patrik (2005) A Study on Creativity Index. Hongkong: Centre for Cultural Policy Research, The University of Hong Kong

Jeffrey, Bob \& Woods, Peter (2003) The Creative School: A frameworkfor success, quality and effectiveness. London, New York: RoutledgeFalmer

Kaufman, James C.; Plucker, Jonathan A.; Baer, John (2008) Essentials of Creativity Assessment, New Jersey, Canada : John Wiley \& Sons, Inc., Hoboken

Lavon, Jim (2008)Creative Approaches to Physical Education: Helping children to achieve their true Potential. London, New York: Routledge

Moon, Jennifer (2008) Critical Thinking: An exploration of theory and practice. London, New York: Routledge Taylor Francis Group

Roberts, Ann \& Harpley, Avril (2007) Helping Children to be Competent Learners From Birth to Three. London, New York: Routhledge

Starko, Alane Jordan (2010) Creativity in the Classroom Schools of Curious Delight. Fourth Edition. New York: Routledge

Steger, Manfred D (2001).Globalism: The New Market Ideology. New York: Rowman and Littlefield Publishers, Inc.

Stevenson, Nancy ( 2006) Young Person's Character Education Handbook. Indianapolish: JIST Publishing, Inc

Ward, Thomas B (2007)The Multiple Roles of Educators in Children's Creativity" in Ai-Girl Tan (ed) Creativiy: A Handbook for Teachers. London, New York: World Scientific]

Weintraub, Sandra (1998) The Hidden Intelligence: Innovation through Intuition. Oxford, etc.: Heinemann

Zajda, Josheph (2005) International Handbook on Globalisation, Education and Policy Research Global Pedagogies and Policies. USA, The Netherland: Springer 